\title{
Analysis on Improving the Efficient Teaching of Primary School Music Through Parent-Teacher Cooperation
}

\author{
Abel Gayafay
}

\begin{abstract}
This study generally aimed to determine the effectiveness of parent - teacher collaboration in enhancing academic performance of grade 4 pupils in Music during pandemic in Bulan North Central School-B, Bulan III District during the SY 2020 2021. The respondents of this study were the 28 grade 4 pupils under the researcher. This is a descriptive research design, using the pre - test result to determine the level of academic performance in Music of grade 4 pupils before the intervention was implemented. The post - test was utilized to measure the effectiveness of using the parent - teacher collaboration after it was implemented. Result of the pre - test shows that before the intervention was done, none of Grade 4 pupils got the passing score having the median of 10.85 and the MPS is.42 (43\%) The post - test was conducted after the implementation of the intervention, and findings revealed that the median is 16.28 with the MPS of (65.14\%) having the difference of 5.43 and the MPS is (20.62\%). Additionally, result of the study implies that the intervention used was "Very Effective" utilizing the scale formulated by the researcher. The conduct of this study was very difficult because of many limitation set by this pandemic, yet the researcher was able to finished the study. Thus, it does not prevent the researcher from recognizing the active participation of the respondents. The researcher strongly recommends to the Division Superintendent to utilize the collaboration to improve the academic performance of the learners.
\end{abstract}

Keywords: Enhanced Academic Performance, Parent Teacher Collaboration

\section{Context and Rationale}

Schools around the world continue to struggle with difficult decisions about whether to hold face - to - face classes, provide online instruction, or adopt a blended learning approach. Even children whose schools are holding face -to - face classes are likely to have a fluid year in and out of online instruction as students and teachers test positive for COVID - 19 and proceed through the cycle of quarantining before returning to the classroom.

Each child is vulnerable and can either be moulded to be successful or made to fail in life. According to the Child and Youth Welfare Code of the Philippines, the child is one of the most important assets of the nation, the promotion and enhancement of the child's life and welfare is also anchored on the moral supervision and support given by his parents or guardians. In order for a child to succeed, parents exert a lot of influence on their child's cognitive development in the early years and thus, the contact between home and school should be maintained, especially during the primary school years. Although family background appears to be a powerful determinant of parental involvement, most parents, if duly encouraged, are able to devote extra time and effort to assisting with their children's education, both in the home and school settings (Goodall, \& Vorhaus, 2010).

Parent support and participation are well defined if the, teachers and parents go hand in hand in achieving the progress of the pupils and of the total school community (Evangelista, 2008). Hoover - Dempsey \& Sandler describes parental involvement as a "rich vein" of continued parental influence in the lives of children as they develop through the elementary, middle and high school years. It is a picture that the collaboration of parents and teachers are the foundation of child's education (Blair, 2014). Parental involvement refers to the amount of participation a parent has when it comes to the schooling of his/her children. Some schools foster healthy parental involvement, but sometimes parents has hesitations if they will involve themselves with their children's education while the part of the teacher is to deliver quality education. This must go hand in hand to create a strong partnership in the education of the child. Parents are the first teachers and they have a key role in shaping up their child's character. A balance of education at home and school moulds a student's actual learning. Parental encouragement had played a crucial role in successful students. Their role is not limited to home but involvement in school activities too For the success of the children's education they have to collaborate with the teachers. Parent involvement placed a vital role in the education of children as well as the contribution it gives to the society. Although, there are programs and current practice on parental involvement in the Philippines, national policies and framework are not in placed to support Early Childhood Education. Statistics shows the low level of reading competence of children, studies reveal the gap in understanding PI in parents' perspective, and the Philippine EFA goals recommends to expand access of parental involvement programs in every barangays. Nowadays it needs that parents and teachers must work together for the achievement of children's education (Selangan, 2015).

This implies that benefits of a strong partnership of parent and teachers create a good results on child's education. Parental encouragement and support for learning activities at home combined with parental involvement in schooling is critical to children's education. A growing body of research shows that building effective partnerships between parents, families and schools to support children's learning leads to improved learning outcomes. Parents are the first and continuing educators of their children. Research also shows that teacher quality, including standards and training in parental engagement, is important for facilitating effective parental engagement. 
The importance of productive partnerships between students, parents, carers, families, schools and the broader community in maximising student engagement and achievement was recognised by the Ministerial Council on Education, Employment, Training and Youth Affairs (MCEETYA) in the Melbourne Declaration on Educational Goals for Young Australians. Considered broadly, parental engagement consists of partnerships between families, schools and communities, raising parental awareness of the benefits of engaging in their children's education, and providing them with the skills to do so.

Through the observation of the researcher, she observed that there are some parents who are not fully involved to their child's education because of their hectic schedule and capacity to teach their child. In view of these, the researcher being teacher III and handling MAPEH found out that his students lack of competency in MUSIC especially in the valuing the notes and rest based from the pre test conducted by the researcher. Out of 28 grade 4 pupils, only 10 got the passing score. The result was so alarming. Thus he was motivated to conduct this study using the parent - teacher collaboration to enhance the academic performance of his pupils in music. Meanwhile, while the future remains unknown, the researcher would like to find out the effectiveness of working together with parents to support and empower the education of their child and can help establish the structures that learners will need to receive the quality education they deserve, and bring stability in a time of uncertainty in Bulan North Central School -B, Bulan III.

\section{Review of Related Literature}

Family - school and community partnerships are re defining the boundaries and functions of education. They enlarge parental and community capacity; they create conditions in which children learn more effectively. In these ways they take education beyond the school gates (Muller, 2009). The best tip for school success is to make sure those parents and teachers are working together as allies. Sometimes, though, it can seem as though there's a chalk line drawn down the middle of your child's life. On the home side, there are all the things you know about your child, the help you give her for homework and her social development with siblings and peers. On the school side of the line, there are all the things your child's teacher knows about her, the help she's getting with her school work and her social development with peers.

The information on both sides can be combined to create a fuller understanding of your child. This is not only of benefit to her but also to you and her teachers. Try these tips for creating a great relationship with your child's teacher. Most teachers think about having a good relationship with parents. In the new normal, there should be a stronger home and school partnership that can facilitate better and more consistent communication and collaboration between teachers and parents. Communication of learning goals, expectations, and feedback can help sustain the needed collaborative relationship between the parents, and the teacher. To do this, the school can create opportunities that can teach parents how to teach their children do the task in the module and even, nourish their children's curiosity at home to read their module. In the new normal, sustainable and supportive external partnerships with local government units, non - government organizations, and other institutions that can help in enabling a responsive education continuity program should be explored. As schools explore these possibilities for partnership, school leaders and administrators should always keep in mind the need to maintain and guard their institution's integrity and independence from any self - serving motives that can interfere with the school's vision and goals.

It's something parents hear all the time, but it bears repeating. One of the keys to parents and teachers working together is to have good communication. What may not be clear is that communication works both ways. Parent teacher relationships only work well if a teacher not only puts in the effort to respond to your concerns and questions but also reaches out to share concerns and compliments with you. Dealing with a difficult teacher is hard but not as uncommon as you may think. If you feel as though your child's teacher is being unfair or isn't sharing as much information as she should, it's time for a parent - teacher conference to ask some questions about what's going on. Just keep in mind that in order to get the most out of your time, it's important to schedule a meeting ahead of time. Just as the teacher catching you on the playground isn't appropriate, neither is you pulling her aside at a school function. Not all child have an easy change to school or enjoy being at school. In fact, it's estimated that up to $5 \%$ of children show signs of school refusal behaviors at some point in their school career. And each day innumerable kids complain of being bored at school.

Some parents shoulder the blame and responsibility for their child's problems, not talking with the school because they feel as if it's their issue alone to deal with. Some parents get the feeling that the school is passing judgment on their parenting when they receive a phone call asking to sit down and talk about their child. That's not always the case. In these situations, sitting down to work out solutions together is the best way to deal with the problem. Building partnerships between parents and teachers can rely on teachers listening to parents and parents taking the time to understand where teachers are coming from. Sometimes parents and teachers both are guilty of dismissing the other's viewpoint.

As a parent, the more dismissed you feel, the less likely you are to participate in your child's education. As a teacher, the less you feel like you're being heard, the more likely you are to stop communicating with a parent. Things that may seem confrontational, like an outline of what kind of homework help a teacher wants from a parent or a parent outlining what the school needs to do to accommodate a child's peanut allergy, aren't always as demanding as they appear. The end goal is the same for both parent and school: helping kids be responsible, safe and successful.

On the other hand, not all parents can monitor their children's progress. Some are incompetent about how to do it because of illiteracy. This situation is more prevalent in rural areas or in remote places. It is a fact that a lot about what parents lack, especially parents who live in poverty. 
Parental involvement is important, but how is it fair to ask these parents to do more? Especially since these are the same groups, who are more likely to have less formal education while being more likely to be essential workers or be more directly impacted by the pandemic economically and health - wise? (Albertson, 2012).

Much of the desire of parents to collaborate to teachers on their child's education but yet they are hesitant to do it because they are not equipped due to illiteracy. Some have not graduated from elementary education or some have not gone to school for formal education. In line with this, parents can tap any members of the family to act as para teacher with their support and supervision.

However, just as images of teaching and learning environments vary, so do images of good parent - teacher relationships. At one end of the spectrum, the image of a good relationship is an effective separation of roles and functions between home and school, an optimal social distance combined with mutual respect. The family meets the schools expectations efficiently, and the school effectively educates the child without undue demands on the home.

On the other hand, not all parents can monitor their children's progress. Some are clueless about how to do it because of illiteracy. This situation is more prevalent in rural areas or in remote places. Parental involvement is important, but how is it fair to ask these parents to do more? Especially since these are the same groups, who are more likely to have less formal education while being more likely to be essential workers or be more directly impacted by the pandemic economically and health - wise? This shows that it needs the partnership of parent and teacher must take place (Reyes, 2020). It is a fact that parents know their children more than any teacher does while teachers know how to give instructions very well. If both of what they know will be combined, educating the children amidst this pandemic can succeed. The skills parents and teachers have a common purpose: to support the continuous learning of the children. This is the very foundation of a stronger partnership. The collaboration of both is very essential to the continuity of the learner's education.

The Department of Education (DepEd) issued the DepEd order No.018, s.2020 dated July, 20, 2020 otherwise known as the POLICY GUIDELINES FOR THE PROVISION OF LEARNING RESOURCES IN THE IMPLEMENTATION OF THE ASIC EDUCATION LEARNING CONTINUITY PLAN. The Rationale for this is in response to the public health brought about by the COVID - 19. It calls the Deped to be responsive, innovative and resourceful in delivery of quality, accessible relevant, and liberating education. It would like to ensure that learning opportunities are provided to our learners in safe manner. Thus, the collaboration of parent and teacher in child's education is very vital in this present situation (Briones, 2020).

It is stipulated in DepEd order 018 the continuity of education in this pandemic. Further, in response to this, parental support and guidance is need. It is stated further in this guideline that, orientation among parents for the effectiveness of modular learning approach is needed in order to deliver quality education during Pandemic. It really appears that parent and teachers are strong pillars to child's education. Further, it is clear in this guideline that the DepEd will provide the module learning materials and to assure the effectiveness of this modular learning approach, it needs the collaboration of the parent and teacher. It is stated further in this guideline that, orientation among parents for the effectiveness of modular learning approach is needed in order to deliver quality education.

In line with these, Sorsogon Schools Division conducted a virtual orientation on Modular Learning, which was participated by the Teachers and Parents in relation for the opening of classes for the School Year 2020 - 2021, wherein they are going to adapt the blended learning approach. This orientation was followed by the Virtual Dry - Run for Schools Handling Blended Learning”, and participated by the parents, and teacher in Sorsogon.

\section{Research Questions}

This action research initiative desires to determine the effectiveness of parent teacher collaboration on enhancing academic performance of grade 4 pupils in Music during pandemic in Bulan North Central School -B, Bulan III District during the SY 2020 - 2021. Specifically, it will seek answer the following questions:

1) What is the level of academic performance of grade 4 pupils in Music in Bulan North Central School -B, Bulan III District utilizing their score in the pre - test?

2) What is the level of effectiveness of parent teacher collaboration during pandemic?

3) What is the effect of the implemented intervention, and strategies in level of academic performance of grade 4 pupils utilizing the result of the post - test?

\section{Scope and Limitations}

This study will focus on determining the effectiveness of parent teacher collaboration enhancing academic performance of grade 4 pupils in Music during pandemic in Bulan North Central School -B, Bulan III District during the SY 2020 - 2021. This study will commence upon the approval of this proposed action research. The descriptive correlation research design will be used in this study. The respondents of the study will be the 28 grades 4 - Dahlia enrolled Bulan North Central School -B, Bulan III District during the SY 2020 - 2021.

In generating the data and information to be used in this study, the researcher will utilize the result of the pre - test as the baseline data to measure the effectiveness of parent teacher collaboration to enhance pupils achievement in Music. This study will use the different statistical tools in analyzing the generated data such as frequency count, percentage, mean, $\mathrm{t}$ - test. All significant levels will e set at 0.0t alpha.

\section{Methodology}

This action research will employ descriptive method of research in discussing the answers of the three research 
questions posted.

\section{Sampling}

The participants of the study will be the 28 grades 4 Dahlia of Bulan North Central School -B, Bulan III District during the SY 2020 - 2021. This is a total numeration. Thus, sampling is not needed.

The table below shows the number of participants of the study

\begin{tabular}{|c|c|c|}
\hline Grade Level & Number of Pupils & Percentage \\
\hline Male & 19 & $67.9 \%$ \\
\hline Female & 9 & $32.1 \%$ \\
\hline Total & 28 & $100 \%$ \\
\hline
\end{tabular}

\section{Data Collection}

The researcher will use the researcher made pre - test to gather the needed data in the action research proposal. To determine the effectiveness of the parent - teacher collaboration, result of the post test is needed. For question number 1 . The teachers will assess the level of academic performance of the pupils using the pre - test to determine their knowledge in music. For question \# 2 - Various outputs of the pupils during the conduct of the project the parent teacher collaboration to enhance the academic performance of grade 4 pupils in music and to specify the level of effectiveness of the intervention implemented in line with the parents -teacher collaboration For question \#3 Using the same assessment tool which is the post - test after the implementation of the intervention will be conducted.

\section{Ethical issues}

Upon the approval of the proposed action research permission the researcher will administer the pre - test to grade 4 pupils under him before he implement the Parent teacher collaboration strategy in improving pupil's academic performance in music. Result of the pre - test will measure the level of academic performance of the respondents. The teacher will invite the parents to come for an orientation about their involvement in the education of their child tin order to improve their academic performance in music. After their consent, the teacher will monitor if they are actually guiding their children to do their activity in the module. The researcher will inform the parents that they must collaborate to teacher for the success of their child's education. After such, the teacher will give the post - test to the pupils to determine the extent of effectiveness of the parent - teacher collaboration in improving their attitudes towards learning science. Further, the confidentiality of the information supplied by respondents will be observed and its secrecy of must be respected. Likewise, parents will be oriented about the purpose of this study. .

\section{Plan for Data Analysis}

Data analysis will vary from one problem to another as discussed in this section these are as follows: For question number 1 , a simple summation of data gathered from the pre - test will be considered. For question number 2 - Rating scale will be used and data will be analysed using simple mean with the following interpretation: 95 - 100 - Higly effective; 94 - 87.76 - Effective; 87.75 - 81.26 - Moderately Effective; 81.25 - 75 Less Effective; 74 - below not Effective. Rank will also be used to obtain the best intervention in improving the academic performance of the pupils. For question number 3. The result of the post - test will be compared after implementing the intervention and innovation using the table below: Difference will be obtained with the mean score to determine in the intervention conducted is very high (10 and above), high 7 , 5 to 9,999$)$, moderately high $(5$ to 7,49$)$, low 2.55 to 4.99 ) and very low (below 2.4)

\section{Results and Discussions}

Data in table 1 displays the result of the pre - test and post test of the 28 grade 4 pupils in 30 - item test. Pre - test was administered by the researcher before the implementation of the intervention having the Median of 10.85 with the MPS of $(43.42 \%)$. After the implementation of the intervention, post - test was conducted having the Median of 16.28 with the MPS of $(65.14 \%)$. The difference of the pre - test and post - test is $20.62 \% \%$ which signifies that there was a substantial increase. It means that the intervention implanted is "Very Effective" using the scale formulated by the researcher.

Table 2 (A): Pre and Post Survey of using Parent - Teacher Collaboration

\begin{tabular}{|c|c|c|}
\hline Type of test & Median & Mean PL \\
\hline Pre - test & 10.85 & $43.42 \%$ \\
\hline Post - test & 16.28 & $65.14 \%$ \\
\hline Difference & $\mathbf{5 . 4 3}$ & $\mathbf{2 0 . 6 2 \%}$ \\
\hline
\end{tabular}

Legend: PL - performance level

It can be gleaned in the table $2 \mathrm{~B}$ the statistical analysis computation with the degrees of freedom of 27 and the level of significance of $5 \%$. The critical value of 2.05 and a computed value of 12.07 , the decision were to reject the null hypothesis. Since the computed value is greater than the critical value it means that there is a significant difference between the pre - test and post - test

Table 2 (B): Using T - test to test the Significant Difference

\begin{tabular}{|l|l|}
\hline Statistical Bases & Statistical Analysis \\
\hline Degree of Freedom & 27 \\
\hline Level of Significance & $5 \%$ \\
\hline T - test Critical Value & 2.05 \\
\hline Computed T - test value & 12.07 \\
\hline Decision on Ho & Reject \\
\hline Conclusion & Significant \\
\hline
\end{tabular}

\section{Conclusions and Recommendation}

Based form the findings the conclusion was formulated and it was concluded that the median for post - test is higher than the pre - test. The computed values using $\mathrm{T}$ - test is greater than the critical values, it means that there is a significant difference between pre - test and post - test. The intervention is surely significant to use by the respondents.

Based from the conclusions the following recommendations are made: 1) Conduct seminars and training address to the teachers and parents who are part from the collaborations and to maintain the good performance of the pupils in music.2). The possibility of crafting a rigid year - round training program which covers all the necessary activities 
may be implemented so as to improve the performance of the pupils in music.

\section{References}

[1] Arcilla J. (2020), DEPED. Most parent prefer modular learning, Manila Times Newsletter.

[2] Department of Education (DEPED) Order No.018 series of 2020

[3] Honigsfeld, A \& Nordmeye, J. (2020). Teacher collaboration during the global pandemic. An Educational Leadership Special Report. / Volume 77, A New Reality Getting Learning Pages 47 - 50 (article)

[4] Reyes, R. (2016). Parent Teachers Partnerships. A theoretical Approach Teacher Retrieved September 6, $2020 . \quad$ https://raisingareadeama. org/wpcontentuploads/2016/12Parent - Teachers Partnerships - article. pdf.

[5] Malindog, Uy, A (2020). Blended Learning in Virus Hit Philippines. Retrieved 1 - 19 - 20 from https: //theaseapost. com/article/blended - learning - virus - hit - philippines

[6] Lipnan, M. (2012) Training in Education., $2^{\text {nd }}$ edition. Montclair State University, New Jersey, Online ISBN9780511840272.

[7] Morin, A. (2020). How parent and Teachers can work together for the child's benefit. Very well family. 